\title{
Methodological approach to assessing the efficiency of the use of digital technologies in the activities of customs authorities
}

\author{
Elena Barausova, Yuliya Lebedinskaya, and Evgeniya Nigay* \\ Vladivostok State University of Economics and Service, Vladivostok, Russia
}

\begin{abstract}
In conditions of limited time, which is dictated by the modern rhythm of life, digital technologies are becoming one of the main tools for optimization and rationalization of all spheres of human activity. The use of modern digital technologies in the customs system is primarily aimed at increasing the efficiency of its activities. Properties such as quality, speed, transparency, generated with the help of information customs technologies, create prerequisites for stimulating Russia's foreign economic activity and developing the national economy. However, at present, the Federal Customs Service has a number of problems that impede the development of digitalization of customs activities, due to external and internal factors, as well as contradictions in some of the tasks facing the customs authorities. Therefore, the task of analyzing the efficiency of the use of digital technologies in the activities of customs authorities becomes urgent.

The authors of the article proposed a methodological approach to assessing the efficiency of the use of digital technologies in the activities of customs authorities, which is based on assessing the quality of electronic customs services.
\end{abstract}

\section{Introduction}

Currently, an important condition for the use of digital technologies in the activities of customs authorities is the organization of a clear sequence of legislatively enshrined actions that consider the variety of factors in the digital development of this organization. The relevance of the scientific article is evidenced by the unfinished Federal Target Program "Electronic Russia" for 2002-2010, approved by the decree of the Government of the Russian Federation of January 28, 2002, the purpose of which was the total informatization of the activities of state bodies [1] and the unfinished program "Information Society" on 2011-2020 years [2]. To further assess the quality of these programs in the activities of customs authorities, the authors proposed a methodology for assessing the efficiency of the use of digitalization, based on assessing the quality of electronic customs services.

\footnotetext{
*Corresponding author: jenia_nigay@mail.ru
} 


\section{Methods}

The management issues in customs authorities are considered in the works of N.M. Blinova, V.G. Draganova, E.G. Anisimova, R.F. Zaripova, I.V. Kuleshova, Yu.V. Rozhkova, L.A. Popova, N.N. Prosyannikova et al.

Key ideas of digitalization of public administration are considered in the works of $\mathrm{K}$. Bwalia, S. Muchual, K. Raddick, M. Barranekia, T. Jenkins, V. Eggers, S. Folk, A. Remmele, M. Silverman, A. Binay, E.G. Inshakova, Sidorova A.A., Kabashova S.Yu., Arkhipova Z.V., Drozhzhinova V.I., Kupriyatnovsky V.P., Evtushenko S.N. and Namiot D.E.

The works of Alekhina O.V., Kashcheev V.V., Poroshin Yu.B., Lyamin D.M., Ermilov I.S., Ignatieva G.V., Nikitchenko I.S., Filippov L.A., Kurtseva G.R., Malakhova L.A., Matveeva E.S. et al. are devoted to the use of digital technologies in customs and foreign economic activity.

However, in the works of the listed authors, there are no methodological developments for organizing the management of the activities of state bodies, including the customs service, using digital technologies. The problem lies in the contradiction between the importance of using digital technologies in the activities of the Federal Customs Service of Russia, and the lack of a methodological approach to solving issues related to the digitalization of state activities. The theoretical and practical significance of the identified problems and their insufficient elaboration determined the goals and objectives of the study.

As a basis for the research, two theoretical and methodological approaches were used: humanitarian and technocratic. When using a humanitarian approach, we consider information technology to be an important component of human life, which is important both for organizing the activities of customs authorities and for the social sphere associated with foreign economic activity. Within the framework of the technocratic approach, we consider information technologies as a means of increasing the labor productivity of tax authorities and limit their use to the spheres of production and management.

\section{Results}

One of the components of the management of customs authorities is quality control of the provision of electronic public services, which is a continuous process of managerial influences on customs officials, ensuring their purposeful behavior under changing internal and external conditions [4] (Fig. 1). 


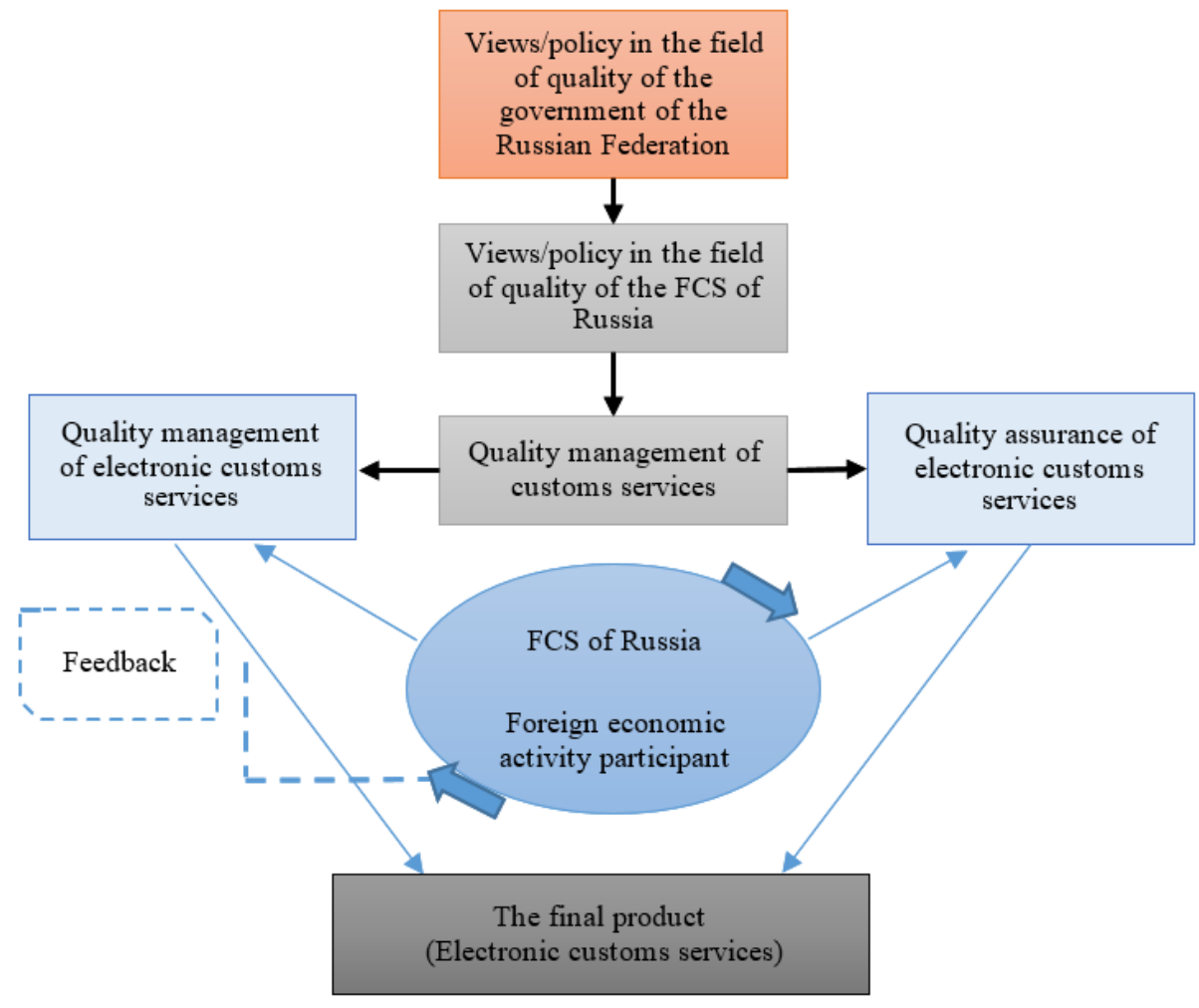

Fig. 1. Process-organizational model for managing the quality of customs services.

The purpose of quality management of customs services is to achieve unification of the actions of all customs officials in the implementation of activities to meet the needs of participants in foreign economic activity with a guarantee of ensuring the economic security of the state and high quality of the provided customs services.

The solution to these problems requires the complexity of the introduced evaluation criteria. However, the monitoring of the quality of electronic customs services currently being implemented in the customs authorities does not give a full picture of the situation and, accordingly, the ability to quickly and timely respond to emerging problems.

To develop the most efficient tool for assessing the quality of the provision of electronic customs services in order to identify shortcomings and further enhance it, it is necessary to rely on three main blocks (Fig. 2).

Let us consider each block in more detail, highlighting the main criteria for assessing the quality of customs services in the framework of the use of digital technologies.

Customs services provided electronically can be assessed using standard analysis and valuation methods. The method of questioning (survey) users of the services of customs authorities in electronic form. Herewith, within the framework of the general mechanism of indicators of the use of digital technologies in the activities of customs authorities, a possible survey of not only third-party organizations and participants whose activities are related to customs, but also conducting surveys among customs officials. 


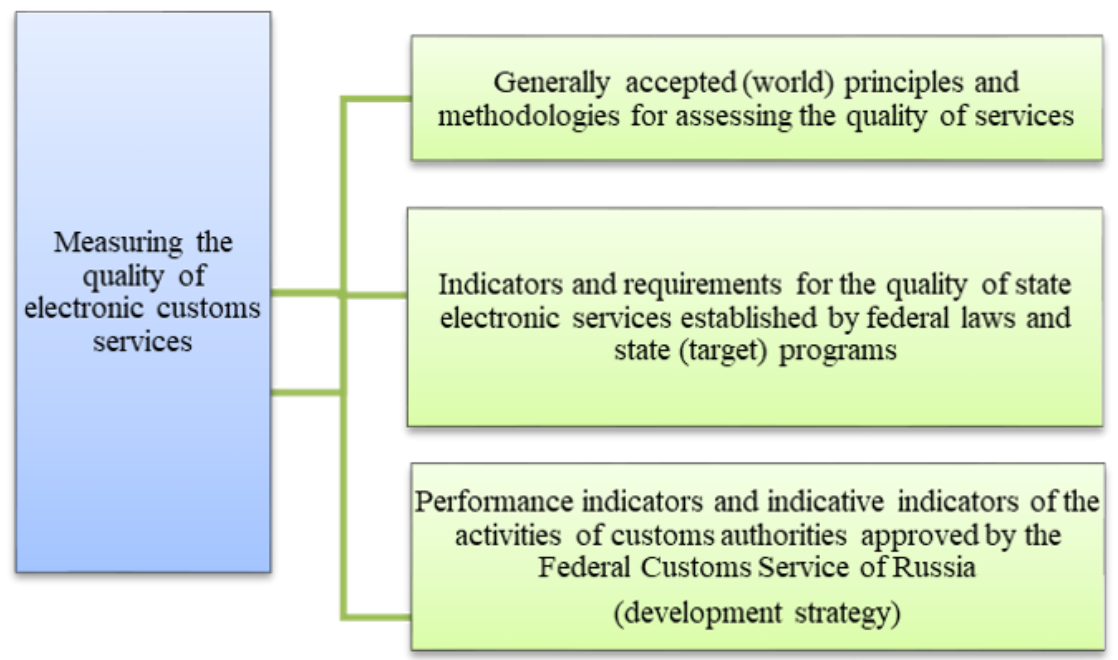

Fig. 2. Fundamental blocks for assessing the quality of customs services in electronic form.

In the Federal Customs Service of Russia, a similar method is used annually in the form of a questionnaire, the results of which are presented on the official website. The method of questioning in the customs authorities is based on a survey of legal entities and individuals.

It should be noted that a separate questionnaire on the provision of customs services in electronic form is not provided. Using the described method, it is possible to assess the impact of digital technologies on the quality of public services provided by customs authorities using the described method only on the basis of comparing the number of users of electronic services and an overall assessment of the degree of satisfaction, as well as the total time of providing customs services. Therefore, it becomes necessary to supplement the questionnaire with such criteria as satisfaction with the receipt of customs services via the Internet, the speed of the portal of public services or the departmental website, comments on the interface of the departmental website (including when searching for the necessary information, instructions, etc.).

In addition, a feedback can be a survey of customs officials who directly respond to requests from users of public services regarding the speed and correctness of the software, as well as the convenience of transmitting the response to the request (provision of services) in electronic form.

Another widespread assessment method is the method based on the calculation of indices, which currently has no implementation in assessing the use of digital technologies in the activities of customs authorities, including the quality of electronic customs services. The index that can be applied in the framework of a systematic assessment of the quality of customs services is the Customer Satisfaction Index (CSI) 5]. The basis for calculating CSI is the correlation of the main assessed criteria of the service to the degree of satisfaction of the consumer of the service. The degree of satisfaction of participants in foreign economic activity with electronic customs services, e.g., can be calculated as the average time for the provision of electronic customs services to the expected time for the provision of electronic customs services. In this case, part of the data for such a calculation will be obtained by the survey method. With regard to the mechanism of indicators of the activities of customs authorities, based on the digitalization of the main processes, the index method will allow, in general, to assess the degree of the expected result (expected indicator) with the actual one.

Among the generally recognized principles and methods of assessment, the main one in developing a methodology for assessing the quality of customs management and, in particular, state services of customs authorities, should be noted the international standard 
ISO 9000 series (ISO 9004: 2009 Managing for the sustained success of an organization - A quality management approach (IDT)) [5]. However, the requirements for the services of customs authorities in electronic form are not enshrined in legislation. Normally, only general provisions for the provision of public services in electronic form, as well as for the organization of the provision of such services, are defined, which is included in the next block of components of the mechanism for assessing the quality of electronic customs services.

The second assessment block is formed on the basis of the requirements established by the regulatory legal acts of the Russian Federation as part of the development of the use of digital technologies in the field of public services. Pursuant to the provisions of the Decree of the Government of the Russian Federation of 03/26/2016 No. 236 "On requirements for the provision of electronic state and municipal services", it is possible to form the following requirements for the provision of services of customs authorities in electronic form, which generally affects their quality $\backslash[6]$ : providing information on the procedure and timing of the provision of customs services in electronic form; ensuring the possibility of forming an electronic request for the provision of electronic customs services (technical component availability, serviceability); ensuring the acceptance and registration by the customs authority of an electronic request and electronic documents necessary for the provision of electronic customs (technical component - exclusion of failures/errors in the transfer of information); ensuring payment for public services and payment of customs duties levied pursuant to the legislation; ensuring the receipt of customs services in electronic form; providing information on the progress of the request for the provision of electronic customs services, etc.

Considering the requirements for the customs authorities in terms of the provision of public services in electronic form, it is possible not only to determine the estimated boundaries, but also the composition of actions of the customs authorities in the provision of such services. In this regard, such requirements should be developed and considered, including in the mechanism of indicators for the use of information technologies in the activities of customs authorities.

The third block of a comprehensive assessment of the quality of customs services is the established indicators within the framework of strategic planning of the activities of customs authorities. For instance, as an indicator of the development of the system of electronic public services, one can use the share of foreign economic activity participants who positively assess the quality of these services in the total number of respondents.

Herewith, when assessing the quality of electronic customs services, it is advisable to consider other indicators of the use of digital technologies: the use of technology for remote release of goods, automation of customs control processes, acceleration of customs operations when customs declaring goods in electronic form; ensuring the transparency of customs operations; reduction of time and number of documents, enhancement of information and technical support of customs activities.

Correlation of the degree of achievement of the indicators set by the target indicators for improving customs regulation and information and technical support will allow identifying the strengths and weaknesses of the development of the customs system and, accordingly, identifying the problems of managing the quality of electronic customs services in the current operating conditions (external and internal factors of development) [7].

Thus, the assessment of the quality of customs services in electronic form should be based on a comprehensive step-by-step analysis of the efficiency of the use of information technologies in the activities of customs authorities, considering the factors that influence the results achieved (Fig. 3). 

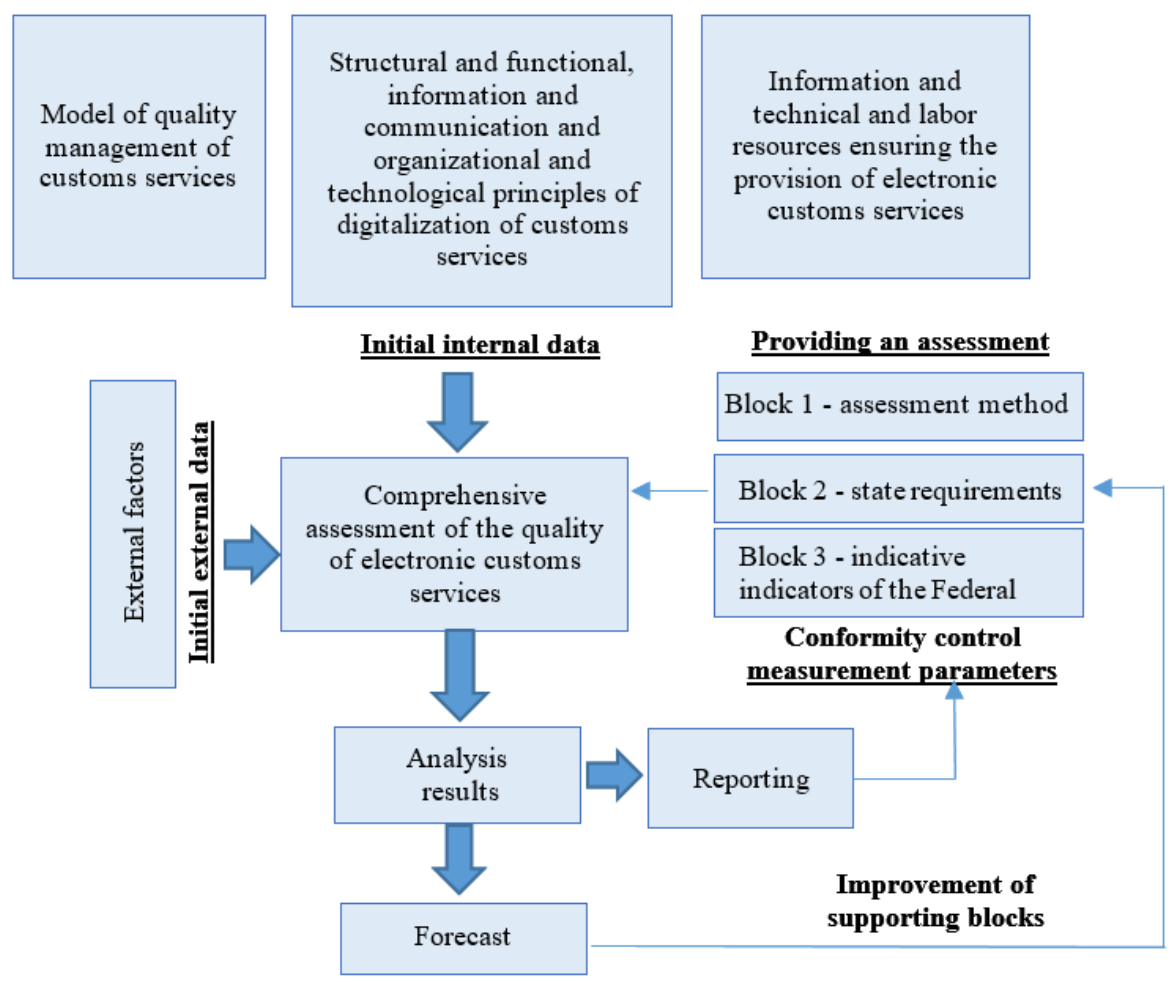

Fig. 3. Evaluation of the quality of electronic customs services.

The process of assessing the quality of electronic customs services indicates the relationship of the given parameters, returning the results and forecast values to the original supporting elements of the assessment. An important step in assessing the quality of digitalization of the customs system, including the provision of electronic services, is to perform control and measuring measures to identify inconsistencies with the indicators established by law and enshrined in the development strategy of the Federal Customs Service of Russia [8].

The proposed scheme for assessing the quality of customs services in electronic form can be interpreted in terms of the methodology for analyzing the efficiency of the use of information technologies in the activities of customs authorities (Fig. 4). 


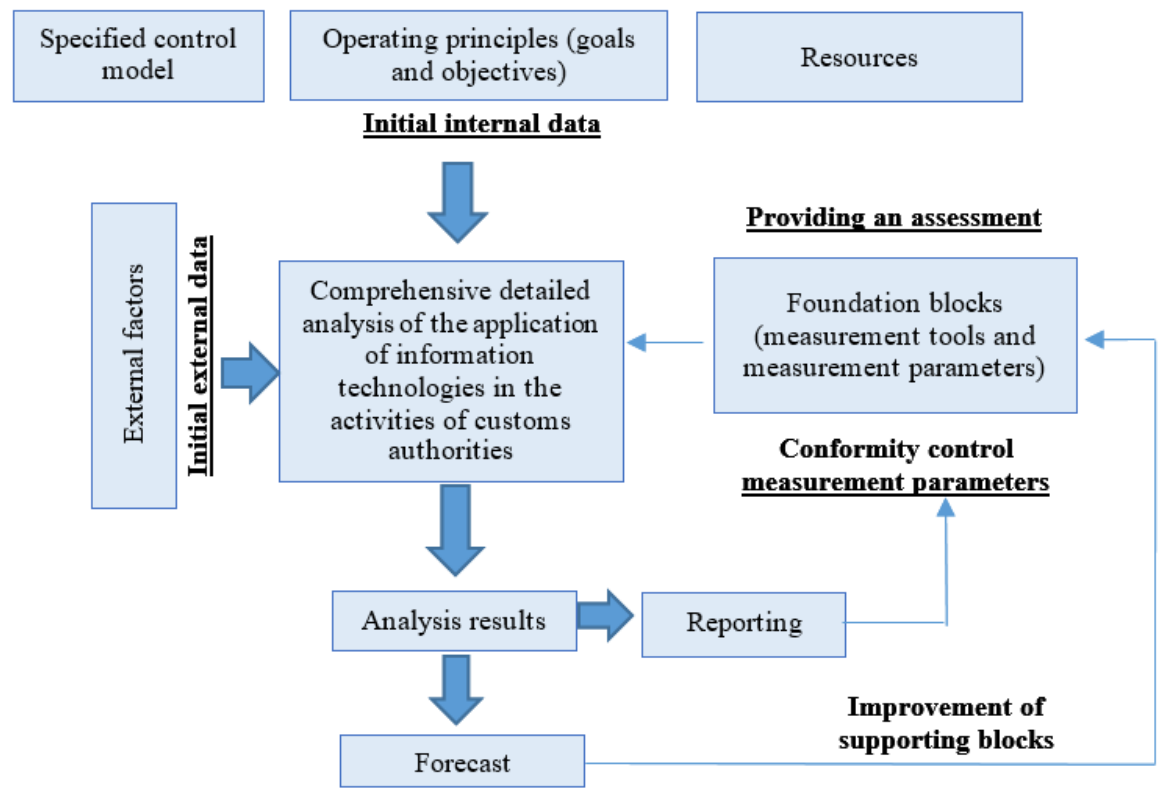

Fig. 4. Analysis of the efficiency of the use of information technology in the activities of customs authorities.

The elements of the methodology for analyzing the efficiency of customs activities using information customs technologies will be: a system of factors (macro- and micro) information and technical development of customs authorities; fundamental blocks for analyzing and assessing the efficiency of activities in the context of digitalization, consisting of the selected analysis methods, legislative requirements for customs activities and established development indicators, which underlie the comprehensive detailed analysis.

\section{Discussion of the results}

In the formation and functioning of the system for managing the activities of the Federal Customs Service in the context of digitalization, it is necessary to consider many elements that affect its development. Therefore, within the framework of the proposed methodology for assessing the efficiency of the use of digital technologies in the activities of customs authorities, it is assumed that the following elements will be included in the management structure of this process: the subject of management (management of customs authorities), the object of management (the process of providing customs services), requirements for the processes of providing customs services, their assessment quality, determination of directions for adjusting the ongoing processes [9]

In view of its versatility and complexity, the proposed approach to analysis and assessment should be used to create an algorithm for the use of information technologies in managing the main processes of customs activities [10,11].

The implementation of the methods and recommendations listed in the study is impossible without consolidating the efforts of the member states of the Eurasian Economic Union aimed at creating and implementing a unified highly efficient information support for the processes of foreign economic activity. The results of such transformations in the Federal Customs Service of Russia should be an increase in multilateral awareness, enhancement of the regulatory framework, cost reduction, standardization and unification of customs operations, enhancement of the quality and efficiency of customs authorities. 


\section{Conclusions}

In the current conditions of problems, contradictions and, at the same time, potential and opportunities, there is a need to develop tools in the form of an algorithm of legislatively enshrined actions to introduce digital technologies into the activities of customs authorities in order to enhance management efficiency. The basis of such an algorithm should be a comprehensive assessment and analysis of both achieved and predicted results.

Practical recommendations of the study can be used when developing a new strategy for the development of customs authorities, creating new or revising existing indicators of its activities.

\section{References}

1. Postanovleniye Pravitel'stva RF ot 28 yanvarya 2002 goda № 65 «O federal'noy tselevoy programme «Elektronnaya Rossiya (2002 - 2010 gody)». http://www.consultant.ru

2. Postanovleniye Pravitel'stva RF ot 15 aprelya 2014 № 313 «Ob utverzhdenii gosudarstvennoy programmy Rossiyskoy Federatsii «Informatsionnoye obshchestvo»: [Electronic resource]. http://www.consultant.ru

3. O.A. Starkova, Upravleniye kachestvom tamozhennykh uslug: avtoreferat dis. ... kand. ekonom. nauk, 4 (2007)

4. Yu.Ye. Gupanova, Aktual'nyye problemy ekonomiki i prava 4, 205 (2014)

5. G. A. Polynskaya, Upravleniye ekonomicheskimi sistemami 12(72), 23 (2014)

6. Postanovleniya Pravitel'stva RF ot 26.03.2016 № 236 «O trebovaniyakh k predostavleniyu $\mathrm{v}$ elektronnoy forme gosudarstvennykh i munitsipal'nykh uslug»: [Electronic resource]. http://www.consultant.ru

7. R. S. Blizkiy, V. E. Malinenko, Y. S. Lebedinskaya, Socio-economic Systems: Paradigms for the Future, Studies in Systems, Decision and Control 314, 521 (2021)

8. G. I. Margarov, E. A. Mitrofanova, L. V. Anikeeva, Socio-economic Systems: Paradigms for the Future, Studies in Systems, Decision and Control 314, 15 (2021)

9. V. M. Svistunov, V. V. Lobachev, S. Manukyan, Socio-economic Systems: Paradigms for the Future, Studies in Systems, Decision and Control 314, 911 (2021)

10. V. M. Serov, A. V. Kozlovskiy, Y. M. Tikhonov, Socio-economic Systems: Paradigms for the Future, Studies in Systems, Decision and Control 314, 923 (2021)

11. Y. S. Lebedinskaya, E. A. Nigay, International J. of Supply Chain Management 8(6) (2019). 